Article

\title{
Decomposition of Glucose-Sensitive Layer-by-Layer Films Using Hemin, DNA, and Glucose Oxidase
}

\author{
Kentaro Yoshida ${ }^{1}{ }^{*}$, Yu Kashimura ${ }^{1}$, Toshio Kamijo ${ }^{2}$, Tetsuya Ono ${ }^{1}$, Takenori Dairaku ${ }^{1}$, \\ Takaya Sato ${ }^{2}\left(\mathbb{D}\right.$, Yoshitomo Kashiwagi ${ }^{1}$ and Katsuhiko Sato ${ }^{2,3}$ (D) \\ 1 School of Pharmaceutical Sciences, Ohu University 31-1 Misumido, Tomita-machi, Koriyama, \\ Fukushima 963-8611, Japan; 714024@ohu-u.jp (Y.K.); t-ono@pha.ohu-u.ac.jp (T.O.); \\ t-dairaku@pha.ohu-u.ac.jp (T.D.); y-kashiwagi@pha.ohu-u.ac.jp (Y.K.) \\ 2 Department of Creative Engineering, National Institute of Technology, Tsuruoka College, 104 Sawada, \\ Inooka, Tsuruoka 997-8511, Japan; kamijo@tsuruoka-nct.ac.jp (T.K.); takayasa@tsuruoka-nct.ac.jp (T.S.); \\ satok@m.tohoku.ac.jp (K.S.) \\ 3 Graduate School of Pharmaceutical Sciences, Tohoku University, 6-3 Aoba, Aramaki, Aoba-ku, \\ Sendai 980-8578, Japan \\ * Correspondence: k-yoshida@pha.ohu-u.ac.jp; Tel.: +81-24-932-8931
}

Received: 8 January 2020; Accepted: 3 February 2020; Published: 4 February 2020

\begin{abstract}
Glucose-sensitive films were prepared through the layer-by-layer (LbL) deposition of hemin-modified poly(ethyleneimine) (H-PEI) solution and DNA solution (containing glucose oxidase (GOx)). H-PEI/DNA + GOx multilayer films were constructed using electrostatic interactions. The $(\mathrm{H}-\mathrm{PEI} / \mathrm{DNA}+\mathrm{GOx})_{5}$ film was then partially decomposed by hydrogen peroxide $\left(\mathrm{H}_{2} \mathrm{O}_{2}\right)$. The mechanism for the decomposition of the $\mathrm{LbL}$ film was considered to involve more reactive oxygen species (ROS) that were formed by the reaction of hemin and $\mathrm{H}_{2} \mathrm{O}_{2}$, which then caused nonspecific DNA cleavage. In addition, GOx present in the LbL films reacts with glucose to generate hydrogen peroxide. Therefore, decomposition of the (H-PEI/DNA + GOx $)_{5}$ film was observed when the thin film was immersed in a glucose solution. (H-PEI/DNA + GOx) $)_{5}$ films exposed to a glucose solution for periods of 24,4872 , and $96 \mathrm{~h}$ indicated that the decomposition of the film increased with the time to $9.97 \%, 16.3 \%, 23.1 \%$, and $30.5 \%$, respectively. The rate of LbL film decomposition increased with the glucose concentration. At $\mathrm{pH}$ and ionic strengths close to physiological conditions, it was possible to slowly decompose the LbL film at low glucose concentrations of 1-10 mM.
\end{abstract}

Keywords: hydrogen peroxide response; layer-by-layer; multilayer thin film; glucose sensitive; stimuli-sensitive

\section{Introduction}

Layer-by-layer (LbL) films have previously been prepared by the alternate deposition of polyelectrolytes (polycation and polyanion) on a solid surface, assisted by electrostatic interaction [1-3]. Various other interactions have also been recently employed to construct LbL films, such as hydrogen bonding $[4,5]$ and sugar-lectin binding [6,7]. The materials employed for this purpose have included synthetic polymers [8,9], polysaccharides [10-12], protein [13-15], and DNA [16,17]. Such layered multilayer films have found application in separation and purification $[18,19]$, sensors $[20,21]$, and drug delivery systems (DDSs) [22-24].

We have recently reported that hydrogen peroxide $\left(\mathrm{H}_{2} \mathrm{O}_{2}\right)$ induced the decomposition of LbL films composed of hemin-modified poly(ethyleneimine) (H-PEI) and DNA [25]. Hemin is an iron porphyrin molecule and the iron porphyrin produces more reactive oxygen species (ROS), such as hydroxy radicals $(\mathrm{OH})$, by reaction with $\mathrm{H}_{2} \mathrm{O}_{2}$ [26,27]. The ROS cause non-specific DNA cleavage [28-30], and $\mathrm{H}-\mathrm{PEI} / \mathrm{DNA} \mathrm{LbL}$ film was consequently decomposed by the addition of $\mathrm{H}_{2} \mathrm{O}_{2} \cdot \mathrm{H}_{2} \mathrm{O}_{2}$ is generated 
by the reaction of substrates and oxidases. LbL films composed of oxidases have been applied in biosensors and stimuli-responsive devices [31-33]. In the present work, we report the preparation of thin LbL films consisting of H-PEI and DNA with glucose oxidase (GOx), and the glucose-induced decomposition of these LbL film (Figure 1). Glucose-sensitive materials respond to the blood glucose level of a diabetic patient; therefore, LbL films composed of GOx can be applied to an insulin DDS [34,35]. The decomposition of LbL films reported in this study is slow due to the stepwise reactions (enzymatic reaction, generation of ROS by hemin, and nonspecific cleavage of DNA). If decomposition of the membrane is slow, then the drug encapsulated in a capsule membrane can be released gradually. The glucose-induced decomposition of the LbL film in this work was achieved by the addition of glucose and the decomposition's dependence on the concentration of glucose was investigated.

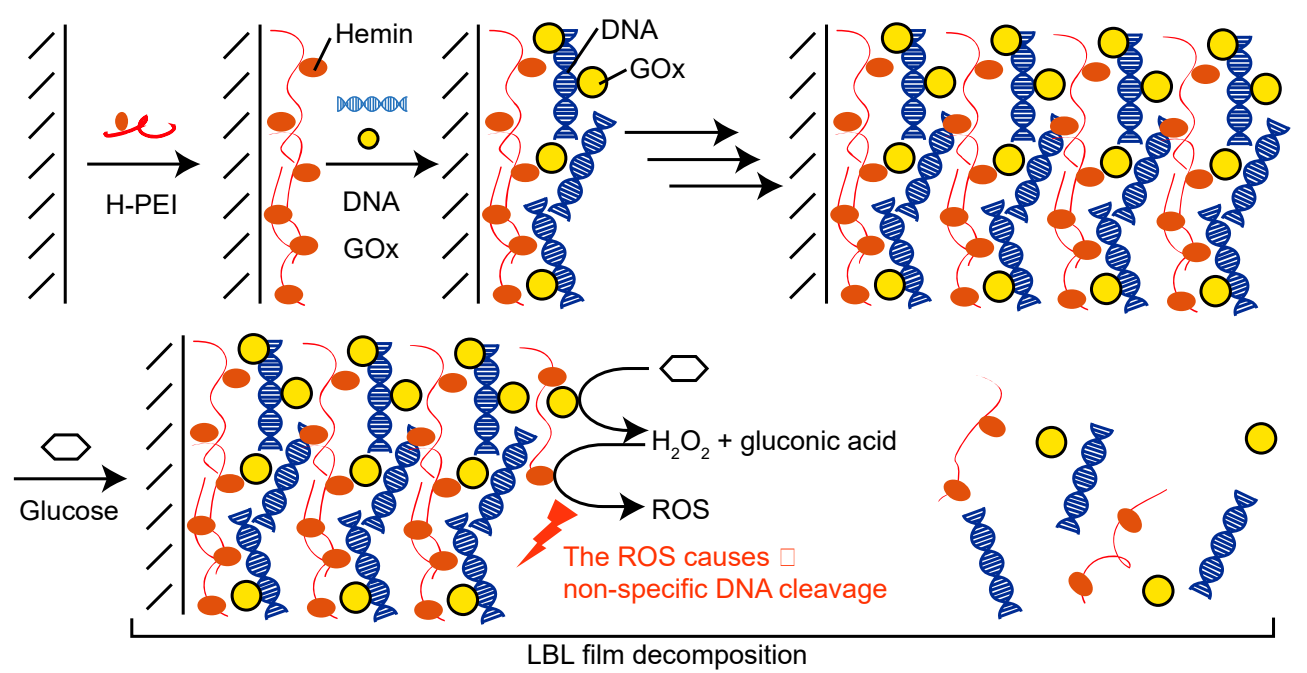

Figure 1. Preparation and decomposition of glucose-sensitive layer-by-layer (LbL) films composed of hemin, DNA, and glucose oxidase (GOx).

\section{Materials and Methods}

\subsection{Materials}

Hemin and poly(ethyleneimine) (PEI, molecular weight; 60,000-80,000) were obtained from Tokyo Chemical Industry Co. (Tokyo, Japan). PEI has a random branched structure with the ratio of primary, secondary, and tertiary amino groups being nominally ca. 1:2:1. DNA (calf thymus) was purchased from Nacalai Tesque Inc. (Tokyo, Japan). GOx was obtained from Sigma-Aldrich Chemical Co. (St. Louis, MO, USA). All other reagents used were of the highest grade and used without further purification.

H-PEI was synthesized as follows. PEI $(100 \mathrm{mg})$ and hemin $(37.9 \mathrm{mg})$ were dissolved in dimethyl sulfoxide, to which N-hydroxysuccinimide $(8.02 \mathrm{mg})$ and 1-ethyl-3-(3-dimethylaminopropyl) carbodiimide hydrochloride $(13.4 \mathrm{mg})$ were added at $4{ }^{\circ} \mathrm{C}$. After $24 \mathrm{~h}$, the reaction mixture was purified by dialyzing with water for 3 days (dialysis tubing, nominal MWCO: 3500, Hampton, NH, USA) and then freeze-dried. The content of hemin residues was 2.2-2.6\% (molar ratio of hemin to amine), as determined from hemin-derived absorbance (at $390 \mathrm{~nm}$ ) using UV-vis absorption spectroscopy. Figure 2 shows the chemical structures of hemin, PEI, and H-PEI. 


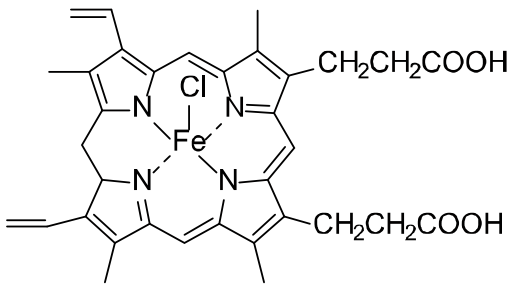

Hemin<smiles>CCCN(CCNCCN)C(C)CCCN</smiles>

PEI

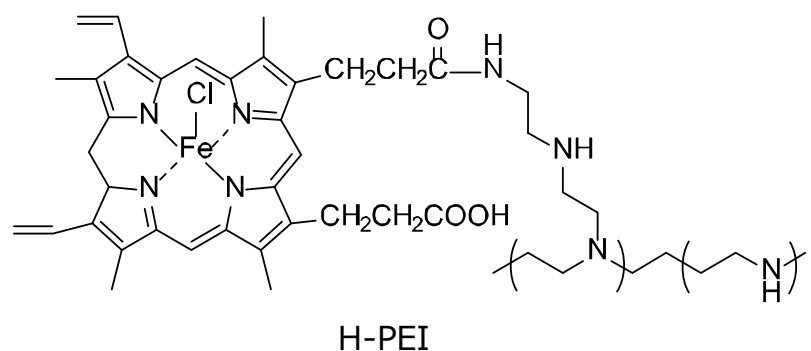

Figure 2. Chemical structures of hemin, poly(ethyleneimine) (PEI), and hemin-modified poly(ethyleneimine) (H-PEI).

\subsection{Apparatus}

A quartz crystal microbalance (QCM; eQCM 10M Garmry, Warminster, UK) was employed for the gravimetric analysis of LbL films consisting of $\mathrm{H}$-PEI and DNA. An $8 \mathrm{MHz}$ AT-cut quartz resonator coated with a gold $(\mathrm{Au})$ layer (surface area $0.2 \mathrm{~cm}^{2}$ ) was used as a probe. The Au surface layer of the quartz resonator was cleaned using piranha solution (a mixture of $\mathrm{H}_{2} \mathrm{O}_{2}$ and $\mathrm{H}_{2} \mathrm{SO}_{4}, 1: 3 \mathrm{v} / \mathrm{v}$ ) and thoroughly rinsed in pure water before use (CAUTION: piranha solution should be handled with extreme care). All QCM operations used flow QCM cells (cell volume ca. $120 \mu \mathrm{L}$; EQCM flow cell kit, BAS, Tokyo, Japan). Atomic force microscopy (AFM; AFM5200S, Hitachi High-Technologies Co., Tokyo, Japan) images were acquired in contact mode at room temperature in air. UV-vis spectroscopy measurements were conducted using a V-560 (Jasco, Tokyo, Japan) spectrometer.

\subsection{Preparation of LbL Films}

H-PEI/DNA films were prepared on the cleaned quartz resonator for QCM analysis. The quartz resonator was immersed in $0.1 \mathrm{mg} / \mathrm{mL}$ H-PEI solution in $10 \mathrm{mM}$ HEPES buffer containing $150 \mathrm{mM} \mathrm{NaCl}$ ( $\mathrm{pH}$ 7.4) for $15 \mathrm{~min}$ to deposit the first H-PEI layer by the hydrophobic force of attraction. After being rinsed in buffer for $5 \mathrm{~min}$ to remove any weakly adsorbed H-PEI, the quartz resonator was immersed in $0.1 \mathrm{mg} / \mathrm{mL}$ DNA solution for $15 \mathrm{~min}$ to deposit DNA by electrostatic interaction. At that time, $0.1 \mathrm{mg} / \mathrm{mL}$ GOx was mixed in the DNA solution. A second H-PEI layer was deposited similarly on the surface of the quartz resonator. The deposition steps were repeated to build up LbL films. Circular glass slides $(18 \mathrm{~mm}$ diameter) and quartz slides $(50 \times 9 \times 1 \mathrm{~mm})$ with LbL films were prepared in the same manner. UV-vis absorption spectra of the LbL films in the working buffer were recorded on a UV-vis spectrometer. For dry AFM observations, the circular glass slides used to prepare each of the $(\mathrm{H}-\mathrm{PEI} / \mathrm{DNA}+\mathrm{GOx})_{5}$ films were rinsed with milli-Q water and dried for $24 \mathrm{~h}$ in a desiccator. AFM images were acquired in AC mode using an Arrow-NCR probe (Toyo Corporation, Tokyo, Japan) at room temperature in air.

\subsection{Decomposition of LbL Films}

The $\mathrm{H}_{2} \mathrm{O}_{2}$-induced decomposition of the (H-PEI/DNA + GOx) $)_{5}$ films was studied using UV-vis absorption spectroscopy. The LbL films prepared on quartz slides were exposed to 1, 10, and $100 \mathrm{mM}$ $\mathrm{H}_{2} \mathrm{O}_{2}$ solution ( $\mathrm{pH}$ 7.4) for 30, 60, 90, 120, 180, and $240 \mathrm{~min}$, and then rinsed with the working buffer for 
$5 \mathrm{~min}$. The films were measured for absorption at a particular time and then subsequently immersed in the $\mathrm{H}_{2} \mathrm{O}_{2}$ solution for the next exposure step.

The glucose-induced decomposition of the (H-PEI/DNA + GOx) films was monitored in the same manner. The LbL films prepared on quartz slides were exposed to 1, 10, and $100 \mathrm{mM}$ glucose solution (pH 7.4) for $0.5,1,1.5,2,3,4,5,6,8,10,24,30,35$, and $48 \mathrm{~h}$. The glucose-induced decomposition of the LbL films was studied by monitoring the resonance frequency change $(\Delta F)$ of the 5-bilayer film-coated quartz resonator in the flow-through cell of the QCM. After rinsing the film-deposited probe with buffer for $5 \mathrm{~min}$, the steady-state frequency was recorded. The film-deposited probe was measured for frequency at a particular time and then subsequently immersed in the glucose solution for the next exposure step.

\section{Results and Discussion}

Figure 3 shows the change in the resonance frequency $(\Delta F)$ of the QCM when the quartz resonator was immersed in the H-PEI solution and DNA/GOx mixed solution. The $\Delta F$ values decreased with the deposition of both H-PEI and the DNA/GOx mixture, which indicated that the (H-PEI/DNA + GOx) film was successfully formed on the surface of the quartz resonator. From the flow QCM data, the change in the resonance frequency of the (H-PEI/DNA + GOx $)_{5}$ film was $-1970 \pm 342 \mathrm{~Hz}(\mathrm{n}=3)$. It is considered that positively charged H-PEI and negatively charged DNA and GOx are deposited by electrostatic attraction, which builds up the LbL film on the quartz resonator surface. There have been other reports on the preparation of LbL films by electrostatic interaction using QCM [36]. LbL films using DNA or GOx driven by electrostatic interactions have been reported by Zhang et al. $[37,38]$ and Kakade et al. It is considered that DNA and GOx are both present in the negatively charged layers because DNA and GOx adsorb to positively charged polymers.

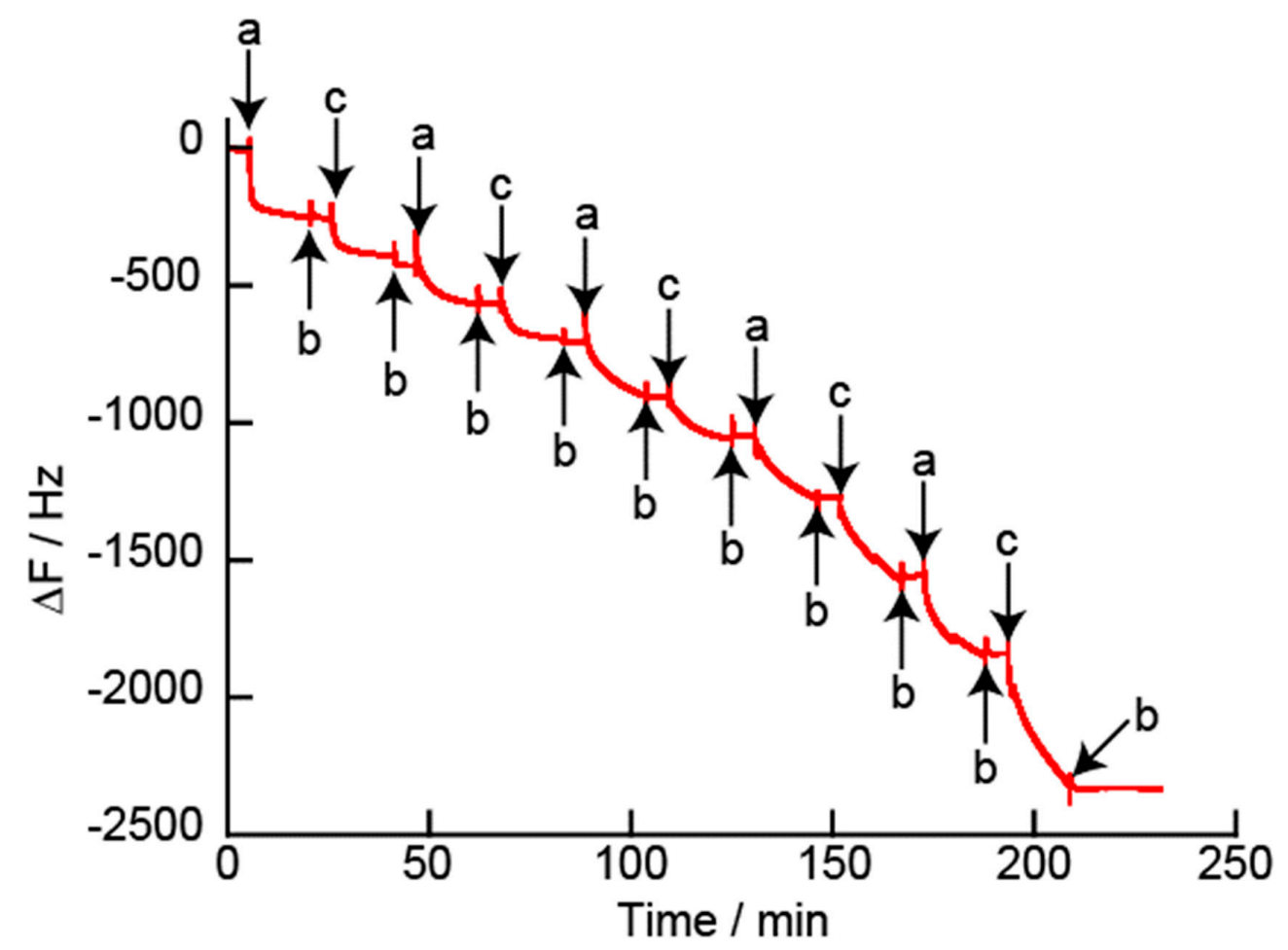

Figure 3. Change in the QCM frequency for the deposition of H-PEI/DNA + GOx $)_{5}$ film at $\mathrm{pH}$ 7.4. The resonator was exposed to (a) $0.1 \mathrm{mg} / \mathrm{mL} \mathrm{H}-\mathrm{PEI}$, (b) $10 \mathrm{mM} \mathrm{HEPES} \mathrm{buffer} \mathrm{solution,} \mathrm{and} \mathrm{(c)} 0.1 \mathrm{mg} / \mathrm{mL}$ DNA (containing $0.1 \mathrm{mg} / \mathrm{mL}$ GOx). 
Figure 4 shows an AFM image and a depth profile of a dried (H-PEI/DNA + GOx $)_{5}$ film. The circular glass slides (18 mm diameter) used to prepare each of the (H-PEI/DNA + GOx $)_{5}$ films were rinsed with milli-Q water and dried for $24 \mathrm{~h}$ in a desiccator. The thicknesses of the LbL films were determined by scratching the film-coated glass slide using a cutter and performing AFM depth profile scans over the scratch. The thicknesses of the (H-PEI/DNA + GOx) $)_{5}$ films were estimated to be $45.68 \pm 15.95 \mathrm{~nm}$.
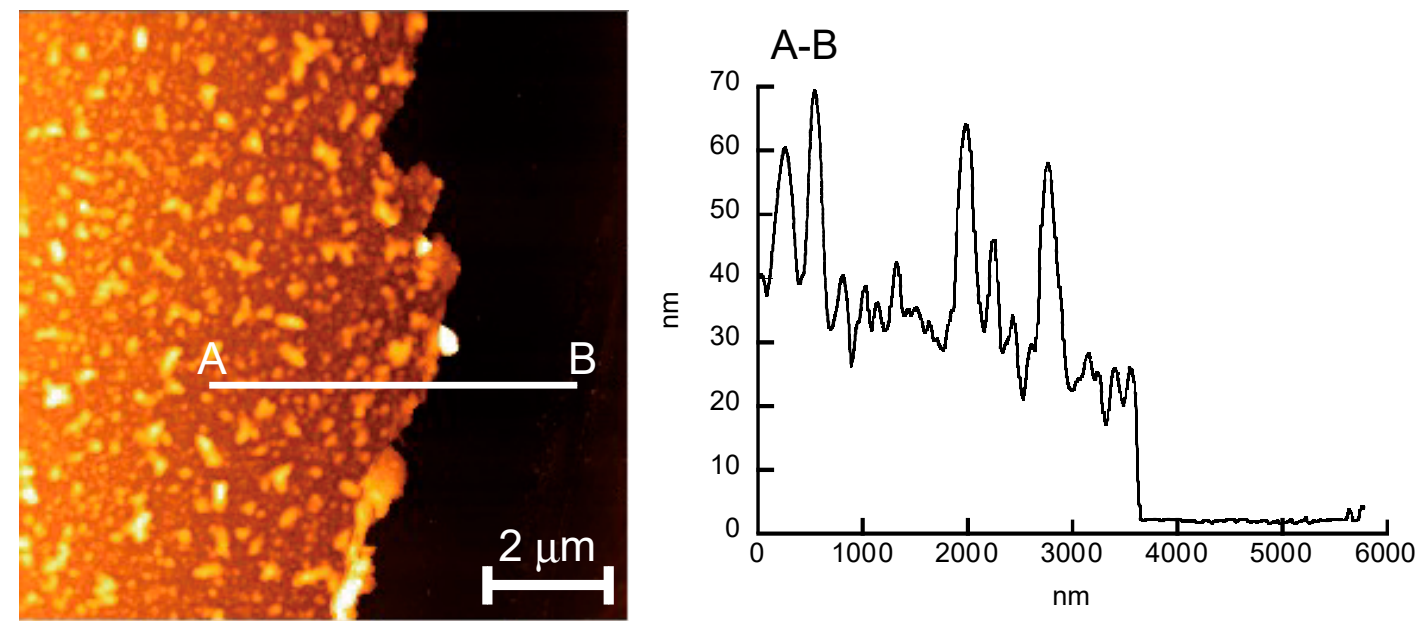

Figure 4. AFM image of the dried (H-PEI/DNA + GOx $)_{5}$ film.

Figure 5 show UV-vis absorption spectra for the (H-PEI/DNA + GOx) $)_{5}$ film and exposure to $100 \mathrm{mM} \mathrm{H} \mathrm{O}_{2}$ solution in $10 \mathrm{mM}$ HEPES buffer containing $150 \mathrm{mM} \mathrm{NaCl}$ (pH 7.4), respectively. The hemin has an absorption at $390 \mathrm{~nm}$ (Figure S1). H-PEI is adsorbed on the surface of the DNA layers, and the LbL film has an absorption maximum derived from hemin. The disappearance of the absorption at $390 \mathrm{~nm}$ was confirmed after the (H-PEI/DNA + GOx) film was exposed to $100 \mathrm{mM} \mathrm{H}_{2} \mathrm{O}_{2}$ solution for $1 \mathrm{~h}$. The iron porphyrin is known to be oxidized by $\mathrm{H}_{2} \mathrm{O}_{2}$, according to Equation (1) [39,40].

$$
\text { Porphyrin-Fe(III) }+\mathrm{H}_{2} \mathrm{O}_{2} \rightarrow \text { Porphyrin-Fe(IV) }=\mathrm{O}+\mathrm{OH}+\mathrm{H}^{+}
$$

The oxidation of iron porphyrin significantly reduces the absorption at $390 \mathrm{~nm}$ (Figure S1). The iron porphyrin contained in hemin produces ROS. The $\mathrm{H}_{2} \mathrm{O}_{2}$ causes the hemin to be degraded, so that the absorption maximum derived from hemin in the film was significantly reduced. Therefore, the absorption at $390 \mathrm{~nm}$ is not suitable for the evaluation of LbL film decomposition. The absorbance of the (H-PEI/DNA + GOx $)_{5}$ film at $260 \mathrm{~nm}$ significantly decreased when immersed in $100 \mathrm{mM}$ $\mathrm{H}_{2} \mathrm{O}_{2}$ solution. The DNA solution has an absorption at $260 \mathrm{~nm}$, and there is no significant change in absorption at $260 \mathrm{~nm}$ after hydrogen peroxide treatment (Figure S2). The absorbance coefficient of GOx is small compared to DNA and hemin (Figure S3). Therefore, GOx has a negligible effect on the absorbance, unless the concentration is high. The oxidation of the iron porphyrin slightly reduces the absorbance contribution at $260 \mathrm{~nm}$, whereas the contribution of the (H-PEI/DNA + GOx) $)_{5}$ film to the absorbance is more significant (Table S1). If ROS are generated near the LbL films, then nonspecific cleavage of DNA is triggered. Yoshida et al. reported the decomposition of H-PEI/DNA nanofilm by $\mathrm{H}_{2} \mathrm{O}_{2}$ [25]. Similarly, the decomposition of the (H-PEI/DNA + GOx) $)_{5}$ films by $\mathrm{H}_{2} \mathrm{O}_{2}$ resulted in a decrease in the absorption maximum derived from DNA. Therefore, changes in the absorption at $260 \mathrm{~nm}$ can be an indicator of the degradability of the (H-PEI/DNA + GOx $)_{5}$ film. 


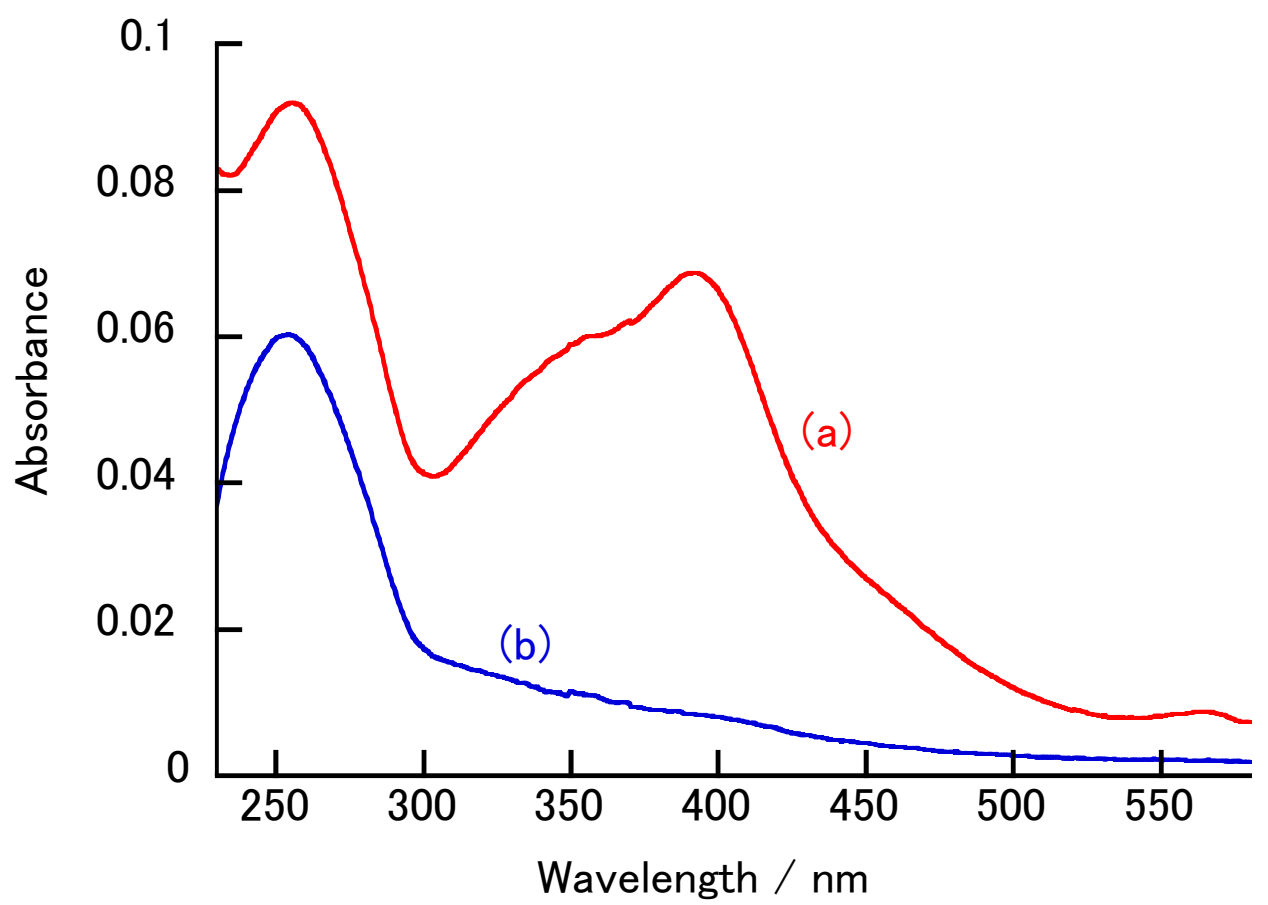

Figure 5. UV-vis absorption spectra for the (H-PEI/DNA + GOx) $)_{5}$ film (a) before and (b) after exposure to $100 \mathrm{mM} \mathrm{H}_{2} \mathrm{O}_{2}$ solution ( $\mathrm{pH}$ 7.4) for $1 \mathrm{~h}$.

The $\mathrm{H}_{2} \mathrm{O}_{2}$-induced decomposition of (H-PEI/DNA + GOx) $)_{5}$ films was investigated using UV-vis absorption spectroscopy (Figure 6). The absorbance at $260 \mathrm{~nm}$ is attributed to hemin, DNA, and GOx. Therefore, if the film is decomposed, the constituent components of the film on the quartz slides are lost, and the absorbance at $260 \mathrm{~nm}$ decreases. Therefore, the decomposition of the LbL film was evaluated using an absorbance ratio. The extent of the $\mathrm{H}_{2} \mathrm{O}_{2}$-induced decomposition of the LbL films was determined using Equation (2).

$$
\mathrm{Abs} s_{t} / \mathrm{Abs}_{0} \times 100=\frac{\begin{array}{c}
\text { absorbance at } 260 \mathrm{~nm} \text { of }(\mathrm{H}-\mathrm{PEI} / \mathrm{DNA}+\mathrm{GOx})_{5} \text { film } \\
\text { when immersed in hydorogen peroxide solution for } \mathrm{t} \text { min }
\end{array}}{\text { absorbance at } 260 \mathrm{~nm} \text { of }(\mathrm{H}-\mathrm{PEI} / \mathrm{DNA}+\mathrm{GOx})_{5} \text { film }} \times 100
$$

When the $(\mathrm{H}-\mathrm{PEI} / \mathrm{DNA}+\mathrm{GOx})_{5}$ film was exposed to the buffer for a long time, the absorbance did not change. On the other hand, the (H-PEI/DNA + GOx) ${ }_{5}$ film immersed in $\mathrm{H}_{2} \mathrm{O}_{2}$ solution showed a decrease in the absorbance ratio, and the decrease was larger as the $\mathrm{H}_{2} \mathrm{O}_{2}$ concentration was higher. Significant decrease in the absorbance ratio can thus indicate the decomposition of the LbL films by $\mathrm{H}_{2} \mathrm{O}_{2}$. In addition, the decomposition of the membrane is affected by the $\mathrm{H}_{2} \mathrm{O}_{2}$ concentration. If the same method is used, then the glucose-induced decomposition of (H-PEI/DNA + GOx $)_{5}$ film can be evaluated. 


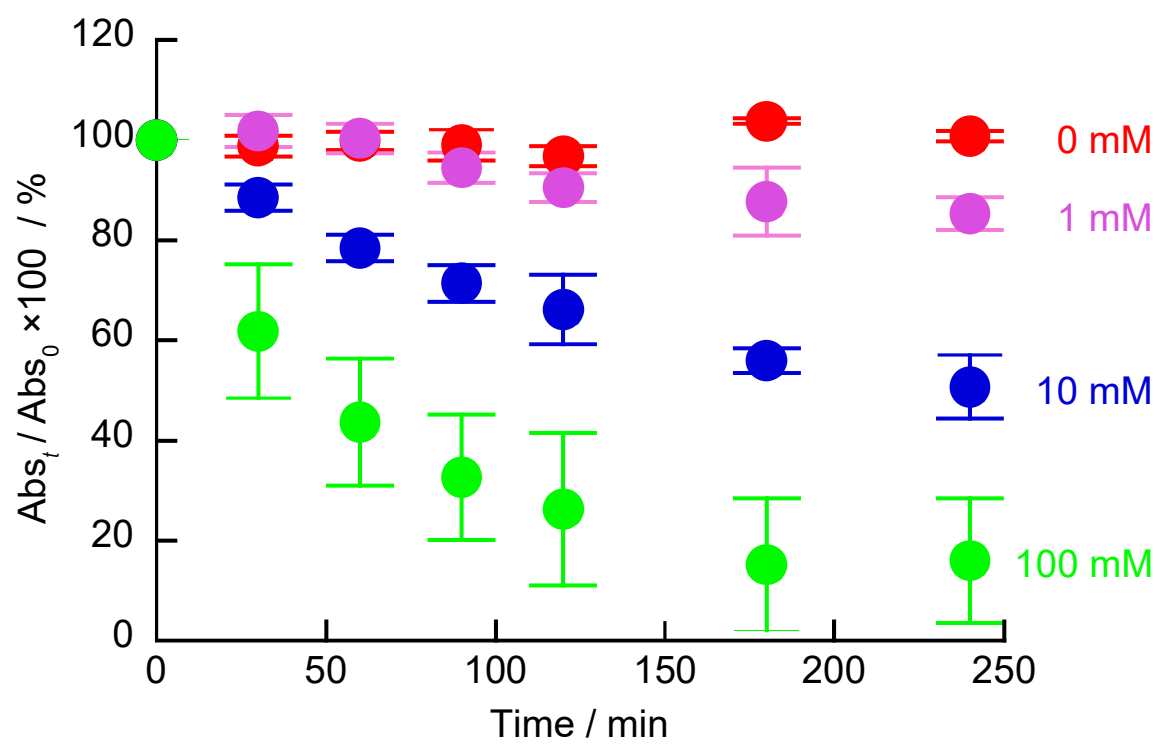

Figure 6. $\mathrm{H}_{2} \mathrm{O}_{2}$-induced decomposition of (H-PEI/DNA $\left.+\mathrm{GOx}\right)_{5}$ films investigated using UV-vis absorption spectroscopy. The LbL films were exposed to 0 (red), 1 (purple), 10 (blue), and $100 \mathrm{mM}$ (green) $\mathrm{H}_{2} \mathrm{O}_{2}$ solutions ( $\mathrm{pH}$ 7.4) for up to $240 \mathrm{~min}$. Error bars represent standard deviation $(\mathrm{n}=4)$.

The glucose-induced decomposition of (H-PEI/DNA + GOx) 5 films was investigated using UV-vis spectroscopy (Figure 7). The glucose-induced LbL films were determined using Equation (3).

$$
\mathrm{Abs}_{t} / \mathrm{Abs}_{0} \times 100=\frac{\begin{array}{c}
\text { absorbance at } 260 \mathrm{~nm} \text { of }(\mathrm{H}-\mathrm{PEI} / \mathrm{DNA}+\mathrm{GOx})_{5} \text { film } \\
\text { when immersed in glucose solution for } \mathrm{t} \mathrm{min}
\end{array}}{\text { absorbance at } 260 \mathrm{~nm} \text { of }(\mathrm{H}-\mathrm{PEI} / \mathrm{DNA}+\mathrm{GOx})_{5} \text { film }} \times 100
$$

When (H-PEI/DNA + GOx) $)_{5}$ films were exposed to 1, 10, and $100 \mathrm{mM}$ glucose solutions for $48 \mathrm{~h}$, the absorbance ratio was $76.1 \%, 70.2 \%$, and $64.0 \%$, respectively. Hemin is an iron porphyrin molecule and is an active cofactor for various enzymes, such as catalase and peroxidase [28]. GOx present in the LbL films reacts with glucose to generate gluconic acid and $\mathrm{H}_{2} \mathrm{O}_{2} . \mathrm{H}_{2} \mathrm{O}_{2}$ present in the LbL films reacts with hemin to generate ROS. The nonspecific cleavage of DNA by ROS promotes the partial degradation of the LbL films. In addition, the rate of LbL film decomposition increased with the glucose concentration. The decomposition rate of the film immersed in the glucose solution was slower than that immersed in the $\mathrm{H}_{2} \mathrm{O}_{2}$ solution. However, the influence of the glucose concentration on the decomposition of the (H-PEI/DNA + GOx $)_{5}$ film was less than that from the $\mathrm{H}_{2} \mathrm{O}_{2}$ concentration. GOx and glucose are enzymatic reactions; therefore, $\mathrm{H}_{2} \mathrm{O}_{2}$ is generated slowly and the degradation of the $\mathrm{LbL}$ film is delayed. Therefore, at $\mathrm{pH}$ and ionic strengths close to physiological conditions, it is possible to slowly decompose the LbL films at a low glucose concentration (1-10 mM). 


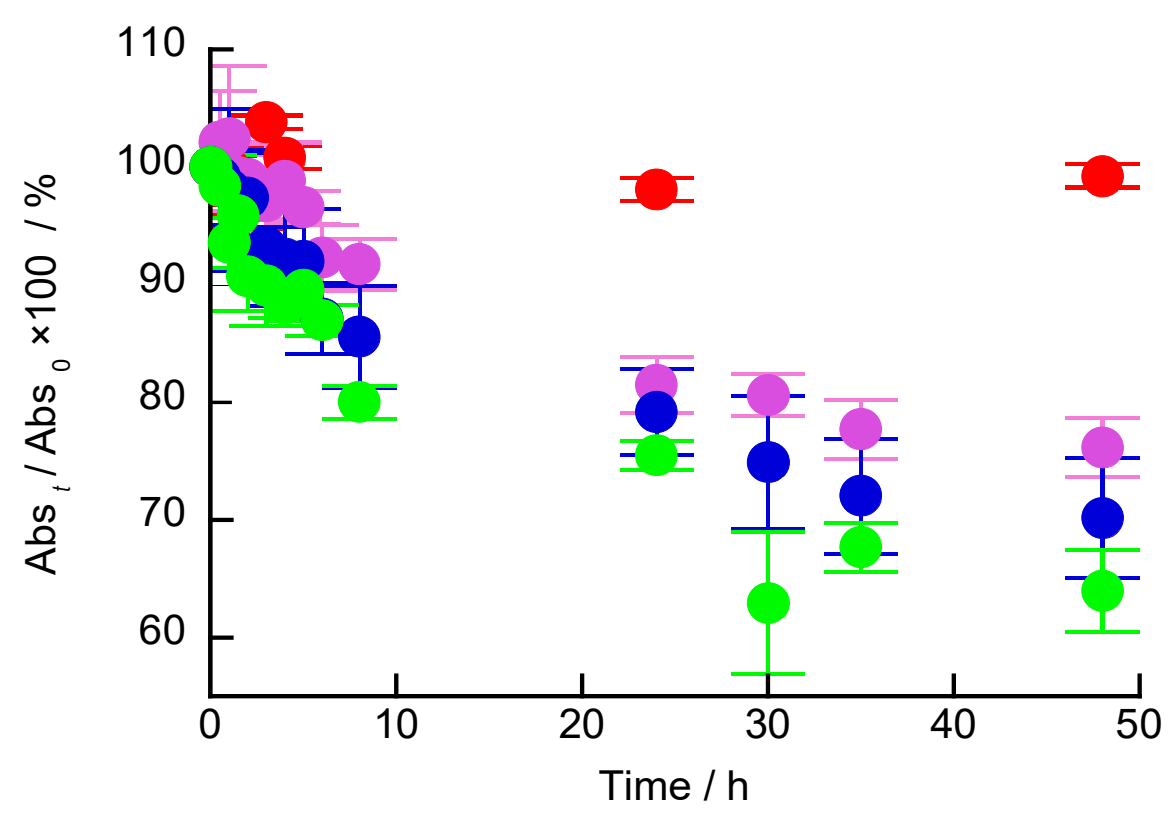

Figure 7. Glucose-induced decomposition of (H-PEI/DNA + GOx $)_{5}$ films investigated using UV-vis absorption spectroscopy. The LbL films were exposed to $0 \mathrm{mM}$ (red), $1 \mathrm{mM}$ (purple), $10 \mathrm{mM}$ (blue), and $100 \mathrm{mM}$ (green) glucose solutions ( $\mathrm{pH} 7.4$ ) for up to $48 \mathrm{~h}$. Error bars represent standard deviation $(0 \mathrm{mM} ; \mathrm{n}=4,1,10$, and $100 \mathrm{mM} ; \mathrm{n}=3$,).

The glucose-induced decomposition of (H-PEI/DNA + GOx) $)_{5}$ films was investigated using the QCM (Figure 8). The extent of the decomposition was calculated from the change in the resonance frequency (Equation (4)).

$$
\text { Decomposed }(\%)=\left(1-\frac{\Delta F_{t}}{\Delta F}\right) \times 100
$$

$\Delta F$ : frequency change of the $(\mathrm{H}-\mathrm{PEI} / \mathrm{DNA})_{5}$ films

$\Delta F_{t}$ : frequency change difference between blank and $(\mathrm{H}-\mathrm{PEI} / \mathrm{DNA})_{5}$ films immersed in glucose solution for $t$ time

When the (H-PEI/DNA + GOx) $)_{5}$ film was exposed to $100 \mathrm{mM}$ glucose solution for 24, 48, 72, and $96 \mathrm{~h}$, the extent of decomposition was $9.97 \%, 16.3 \%, 23.1 \%$, and $30.5 \%$, respectively. However, the results of Figure 8 show less decomposition of LbL films than expected compared to Figure 7. Compared to QCM operation, the amount of decomposition of LbL films immersed in glucose solution during UV operation is greater. The absorbance ratio is influenced by hemin oxidation; therefore, there was a difference in the amount of membrane degradation. The glucose-induced decomposition of LbL films reported by Sato et al. occurred for $1 \mathrm{~h}$ when glucose was added [41]. On the other hand, from the QCM results, a longer immersion time in $100 \mathrm{mM}$ glucose solution resulted in greater decomposition of the LbL films. Depending on the glucose concentration, it is possible to slowly decompose the $(\mathrm{H}-\mathrm{PEI} / \mathrm{DNA}+\mathrm{GOx})_{5}$ film. 


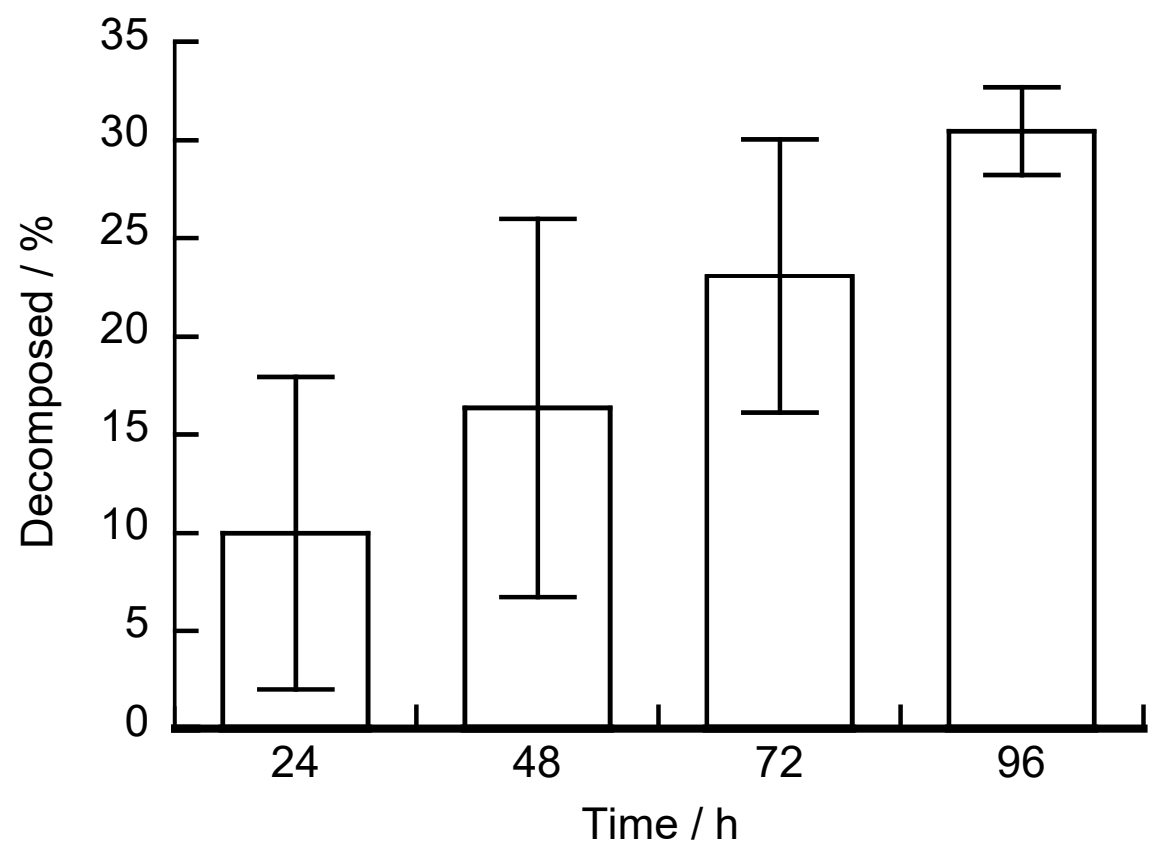

Figure 8. Glucose-induced decomposition of (H-PEI/DNA + GOx $)_{5}$ films was investigated using a QCM. The LbL film was exposed to $100 \mathrm{mM}$ glucose solution ( $\mathrm{pH} 7.4$ ) for up to $96 \mathrm{~h}$. Error bars represent standard deviation $(n=3)$.

\section{Conclusions}

$(\mathrm{H}-\mathrm{PEI} / \mathrm{DNA}+\mathrm{GOx})_{5} \mathrm{LbL}$ films were prepared by alternate immersion of a substrate in H-PEI solution and DNA solution (containing GOx). When the (H-PEI/DNA + GOx) $)_{5}$ films were immersed in a $\mathrm{H}_{2} \mathrm{O}_{2}$ solution, partial decomposition of the LbL films was observed. The iron porphyrin in hemin produces more $\mathrm{ROS}$ from the reaction with $\mathrm{H}_{2} \mathrm{O}_{2}[26,27]$. The ROS cause non-specific DNA cleavage; therefore, the decomposition of the LbL films composed of DNA was observed. Furthermore, partial degradation was observed when the membrane was immersed in a glucose solution. GOx present in LbL films produced $\mathrm{H}_{2} \mathrm{O}_{2}$ from glucose. These LbL films decomposed under physiological conditions with various glucose concentrations, which suggests that a glucose stimuli-responsive nanofilm could be realized. We have developed other glucose- and pH-responsive thin films [42,43]; however, the $(\mathrm{H}-\mathrm{PEI} / \mathrm{DNA}+\mathrm{GOx})_{5}$ film has a very slow decomposition. If a drug could be encapsulated in this thin film, then there is a possibility that a system capable of drug release over a long time period, depending on the substrate, could be realized.

Supplementary Materials: The following are available online at http://www.mdpi.com/2073-4360/12/2/319/s1, Figure S1: UV-vis absorption spectra for $30 \mathrm{~g} / \mathrm{mL}$ hemin solution (a) before and (b) after treated with $100 \mathrm{mM} \mathrm{H}_{2} \mathrm{O}_{2}$ ( $\mathrm{pH}$ 7.4) for $1 \mathrm{~h}$. The remaining $\mathrm{H}_{2} \mathrm{O}_{2}$ was consumed by dropping $10 \mathrm{~L}$ of $0.1 \mathrm{mg} / \mathrm{mL}$ catalase into the test solution $(2 \mathrm{~mL})$ and letting it stand for $24 \mathrm{~h}$. Figure S2: UV-vis absorption spectra for $13.6 \mathrm{~g} / \mathrm{mL}$ DNA solution (red) before and (blue) after treated with $100 \mathrm{mM} \mathrm{H}_{2} \mathrm{O}_{2}$ (pH 7.4) for $1 \mathrm{~h}$. The remaining $\mathrm{H}_{2} \mathrm{O}_{2}$ was consumed by dropping $10 \mathrm{~L}$ of $0.1 \mathrm{mg} / \mathrm{mL}$ catalase into the test solution $(2 \mathrm{~mL})$ and letting it stand for $24 \mathrm{~h}$. Figure S3: UV-vis absorption spectra for $110 \mathrm{~g} / \mathrm{mL}$ GOx solution (pH 7.4). Table S1: Absorbance difference in hydrogen peroxide treatment.

Author Contributions: K.Y. and K.S. designed the work. K.Y. and Y.K. (Yoshitomo Kashiwagi) collected the materials. K.Y. and Y.K. (Yu Kashimura) conducted experimental works on detailed LbL film data. T.K. and T.S. performed the AFM observations. K.Y., T.D., T.O. and K.S. were involved in providing experimental advice and operations. The manuscript was prepared by K.Y and K.S. All authors have read and agreed to the published version of the manuscript.

Funding: This work was supported Kakenhi Grants-in-Aid (Nos. JP18K06791 and JP18K19936) from the Japan Society for the Promotion of Science (JSPS) and the Ohu University Research Fund.

Acknowledgments: This work was partially supported by Kakenhi Grants-in-Aid (Nos. JP18K06791 and JP18K19936) from the Japan Society for the Promotion of Science (JSPS). The Ohu University Research Fund 
is also acknowledged for financial support. The authors thank staff of Tsuruoka College for assisting with the AFM observations.

Conflicts of Interest: The authors declare no conflicts of interest.

\section{References}

1. Decher, G. Fuzzy nanoassemblies: Toward layered polymeric multicomposites. Science 1997, 277, $1232-1237$. [CrossRef]

2. Izquierdo, A.; Ono, S.S.; Voegel, J.C.; Schaaf, P.; Decher, G. Dipping versus spraying: Exploring the deposition conditions for speeding up layer-by-layer assembly. Langmuir 2005, 21, 7558-7567. [CrossRef]

3. Yoshida, K.; Sato, K.; Ono, T.; Dairaku, T.; Kashiwagi, Y. Preparation of nafion/polycation layer-by-layer films for adsorption and release of insulin. Polymers 2018, 10, 812. [CrossRef] [PubMed]

4. Erel, I.; Schlaad, H.; Demirel, A.L. Effect of structural isomerism and polymer end group on the pH-stability of hydrogen-bonded multilayers. J. Colloid Interface Sci. 2011, 361, 477-482. [CrossRef] [PubMed]

5. Tokuda, Y.; Miyagishima, T.; Tomida, K.; Wang, B.; Takahashi, S.; Sato, K.; Anzai, J.-I. Dual pH-sensitive layer-by-layer films containing amphoteric poly(diallylamine-co-maleic acid). J. Colloid Interface Sci. 2013, 399, 26-32. [CrossRef] [PubMed]

6. Inoue, H.; Sato, K.; Anzai, J.-I. Disintegration of layer-by-layer assemblies composed of 2-iminobiotin-labeled poly(ethyleneimine) and avidin. Biomacromolecules 2005, 6, 27-29. [CrossRef]

7. Sato, K.; Imoto, Y.; Sugama, J.; Seki, S.; Inoue, H.; Odagiri, T.; Hoshi, T.; Anzai, J.-I. Sugar-induced disintegration of layer-by-layer assemblies composed of concanavalin A and glycogen. Langmuir 2005, 21, 797-799. [CrossRef]

8. Decher, G.; Hong, J.D.; Schmitt, J. Buildup of ultrathin multilayer films by a self-assembly process:III. Consecutively alternating adsorption of anionic and cationic polyelectrolytes on charged surfaces. Thin Solid Films 1992, 210-211, 831-835. [CrossRef]

9. Hammond, P.T. Form and function in multilayer assembly: New applications at the nanoscale. Adv. Mater. 2004, 16, 1271-1293. [CrossRef]

10. Rochín-Wong, S.; Rosas-Durazo, A.; Zavala-Rivera, P.; Maldonado, A.; Martínez-Barbosa, M.E.; Vélaz, I.; Tánori, J. Drug release properties of diflunisal from layer-by-layer self-assembled $\mathrm{k}$-carrageenan/chitosan nanocapsules: Effect of Deposited Layers. Polymers 2018, 10, 760. [CrossRef]

11. Shutava, T.G.; Livanovich, K.S.; Sharamet, A.A. Layer-by-layer films of polysaccharides modified with polyethylene glycol and dextran. Colloids Surf. B Biointerfaces 2019, 173, 412-420. [CrossRef] [PubMed]

12. Li, K.; Zhu, J.; Guan, G.; Wu, H. Preparation of chitosan-sodium alginate films through layer-by-layer assembly and ferulic acid crosslinking: Film properties, characterization, and formation mechanism. Int. J. Biol. Macromol. 2019, 22, 485-492. [CrossRef] [PubMed]

13. Houska, M.; Brynda, E.; Bohatá, K. The effect of polyelectrolyte chain length on layer-by-layer protein/polyelectrolyte assembly—An experimental study. Colloid Interface Sci. 2004, 273, 140-147. [CrossRef] [PubMed]

14. Hashide, R.; Yoshida, K.; Hasebe, Y.; Seno, M.; Takahashi, S.; Sato, K.; Anzai, J. Poly(lactic acid) microparticles coated with insulin-containing layer-by-layer films and their $\mathrm{pH}$-dependent insulin release. J. Nanosci. Nanotechnol. 2014, 14, 3100-3105. [CrossRef] [PubMed]

15. Vander Straeten, A.; Bratek-Skicki, A.; Jonas, A.M.; Fustin, C.A.; Dupont-Gillain, C. Integrating proteins in layer-by-layer assemblies independently of their electrical charge. ACS Nano 2018, 12, 8372-8381. [CrossRef]

16. Lee, L.; Johnston, A.P.; Caruso, F. Programmed degradation of DNA multilayer films. Small 2014, 10, 2902-2909. [CrossRef]

17. Peng, N.; Yu, H.; Wang, Z.; Zhang, Y.; Deng, K.; Li, J.; Lu, L.; Zou, T.; Liu, Y.; Huang, S. Dendrimer-grafted bioreducible polycation/DNA multilayered films with low cytotoxicity and high transfection ability. Mater. Sci. Eng. C Mater. Biol. Appl. 2019, 98, 737-745. [CrossRef]

18. Zhao, Y.; Gao, C.; Van der Bruggen, B. Technology-driven layer-by-layer assembly of a membrane for selective separation of monovalent anions and antifouling. Nanoscale 2019, 11, 2264-2274. [CrossRef]

19. Zou, Y.; Xie, L.; Carroll, S.; Muniz, M.; Gibson, H.; Wei, W.Z.; Liu, H.; Mao, G. Layer-by-layer films with bioreducible and nonbioreducible polycations for sequential DNA release. Biomacromolecules 2014, 15, 3965-3975. [CrossRef] 
20. Locke, A.K.; Means, A.K.; Dong, P.; Nichols, T.J.; Coté, G.L.; Grunlan, M.A. A Layer-by-layer approach to retain a fluorescent glucose sensing assay within the cavity of a hydrogel membrane. ACS Appl. Bio Mater. 2018, 1, 1319-1327. [CrossRef]

21. Jia, Y.; Yu, H.; Zhang, Y.; Dong, F.; Li, Z. Cellulose acetate nanofibers coated layer-by-layer with polyethylenimine and graphene oxide on a quartz crystal microbalance for use as a highly sensitive ammonia sensor. Colloids Surf. B Biointerfaces 2016, 148, 263-269. [CrossRef] [PubMed]

22. Alvarez-Lorenzo, C.; Blanco-Fernandez, B.; Puga, A.M.; Concheiro, A. Crosslinked ionic polysaccharides for stimuli-sensitive drug delivery. Adv. Drug Deliv. Rev. 2013, 65, 1148-1171. [CrossRef] [PubMed]

23. Liu, P. Stabilization of layer-by-layer engineered multilayered hollow microspheres. Adv. Colloid Interface Sci. 2014, 207, 178-188. [CrossRef] [PubMed]

24. Carvalho, J.A.; da Silva Abreu, A.; Tedesco, A.C.; Junior, M.B.; Simioni, A.R. Functionalized photosensitive gelatin nanoparticles for drug delivery application. J. Biomater. Sci. Polym. Ed. 2019, 30, 508-525. [CrossRef] [PubMed]

25. Yoshida, K.; Ono, T.; Dairaku, T.; Kashiwagi, Y.; Sato, K. Preparation of hydrogen peroxide sensitive nanofilms by a layer-by-layer technique. Nanomaterials 2018, 8, 941. [CrossRef] [PubMed]

26. Jiang, B.; Yao, Y.; Xie, R.; Dai, D.; Lu, W.; Chen, W.; Zang, L. Enhanced generation of reactive oxygen species for efficient pollutant elimination catalyzed by hemin based on persistent free radicals. Appl. Catal. B Environ. 2016, 183, 291-297. [CrossRef]

27. Ohbuchi, A.; Kono, M.; Kitagawa, K.; Takenokuchi, M.; Imoto, S.; Saigo, K. Quantitative analysis of hemin-induced neutrophil extracellular trap formation and effects of hydrogen peroxide on this phenomenon. Biochem. Biophys. Rep. 2017, 11, 147-153. [CrossRef]

28. Travascio, P.; Li, Y.S.D. DNA-enhanced peroxidase activity of a DNA-aptamer-hemin complex. Chem. Biol. 1998, 5, 505-517. [CrossRef]

29. Song, M.; Zeng, L.; Hong, X.; Meng, Z.; Yin, J.; Wang, H.; Liang, Y.; Jiang, G. Polyvinyl pyrrolidone promotes DNA cleavage by a ROS-independent and depurination mechanism. Environ. Sci. Technol. 2013, 47, 2886-2891. [CrossRef]

30. Brabec, V.; Pracharova, J.; Stepankova, J.; Sadler, P.J.; Kasparkova, J. Photo-induced DNA cleavage and cytotoxicity of a ruthenium (II) arene anticancer complex. J. Inorg. Biochem. 2016, 160, 149-155. [CrossRef]

31. Salvo-Comino, C.; García-Hernández, C.; García-Cabezón, C.; Rodríguez-Méndez, M.L. Discrimination of milks with a multisensor system based on layer-by-layer films. Sensors 2018, 18, 2716. [CrossRef] [PubMed]

32. Pallarola, D.; von Bildering, C.; Pietrasanta, L.; Queralto, N.; Knoll, W.; Battaglini, F.; Azzaroni, O. Recognition-driven layer-by-layer construction of multiprotein assemblies on surfaces: A biomolecular toolkit for building up chemoresponsive bioelectrochemical interfaces. Phys. Chem. Chem. Phys. 2012, 14, 11027-11039. [CrossRef] [PubMed]

33. Sato, K.; Takahashi, S.; Anzai, J. Layer-by-layer thin films and microcapsules for biosensors and controlled release. Anal. Sci. 2012, 28, 929-938. [CrossRef] [PubMed]

34. Shi, D.; Ran, M.; Zhang, L.; Huang, H.; Li, X.; Chen, M.; Akashi, M. Fabrication of biobased polyelectrolyte capsules and their application for glucose-triggered insulin delivery. ACS Appl. Mater. Interfaces 2016, 8, 13688-13697. [CrossRef] [PubMed]

35. Yoshida, K.; Awaji, K.; Shimizu, S.; Iwasaki, M.; Oide, Y.; Ito, M.; Dairaku, T.; Ono, T.; Kashiwagi, Y.; Sato, K. Preparation of microparticles capable of glucose-induced insulin release under physiological conditions. Polymers 2018, 10, 1164. [CrossRef] [PubMed]

36. Guzmán, E.; Ritacco, H.; Rubio, J.E.F.; Rubio, R.G.; Ortega, F. Salt-induced changes in the growth of polyelectrolyte layers of poly(diallyldimethylammoniumchloride) and poly(4-styrene sulfonate of sodium). Soft Matter 2009, 5, 2130-2142. [CrossRef]

37. Zhang, S.; Demoustier-Champagne, S.; Jonas, A.M. Quantitative collection and enzymatic activity of glucose oxidase nanotubes fabricated by templated layer-by-layer assembly. Biomacromolecules 2015, 16, 2382-2393. [CrossRef]

38. Kakade, S.; Manickam, D.S.; Handa, H.; Mao, G.; Oupický, D. Transfection activity of layer-by-layer plasmid DNA/poly(ethylenimine) films deposited on PLGA microparticles. Int. J. Pharm. 2009, 365, 44-52. [CrossRef]

39. Dunford, H.B. Free radicals in iron-containing systems. Free Radic. Biol. Med. 1987, 3, 405-421. [CrossRef] 
40. Travascio, P.; Witting, P.K.; Mauk, A.G.; Sen, D. The peroxidase activity of a hemin-DNA oligonucleotide complex: Free radical damage to specific guanine bases of the DNA. J. Am. Chem. Soc. 2001, 123, 1337-1348. [CrossRef]

41. Sato, K.; Takahashi, M.; Ito, M.; Abe, E.; Anzai, J.-I. Glucose-induced decomposition of layer-by-layer films composed of phenylboronic acid-bearing poly(allylamine) and poly(vinyl alcohol) under physiological conditions. J. Mater. Chem. B 2015, 3, 7796-7802. [CrossRef]

42. Seno, M.; Yoshida, K.; Sato, K.; Anzai, J.-I. pH- and sugar-sensitive multilayer films composed of phenylboronic acid (PBA)-modified poly(allylamine hydrochloride) (PBA-PAH) and poly(vinyl alcohol) (PVA): A significant effect of PBA content on the film stability. Mater. Sci. Eng. C 2016, 62, 474-479. [CrossRef] [PubMed]

43. Yoshida, K.; Hashide, R.; Ishii, T.; Takahashi, S.; Sato, K.; Anzai, J. Layer-by-layer films composed of poly(allylamine) and insulin for pH-triggered release of insulin. Colloids Surf. B Biointerfaces 2012, 91, 274-279. [CrossRef] [PubMed]

(C) 2020 by the authors. Licensee MDPI, Basel, Switzerland. This article is an open access article distributed under the terms and conditions of the Creative Commons Attribution (CC BY) license (http://creativecommons.org/licenses/by/4.0/). 